\title{
Computer simulation of a composite based on a monolayer of pyrolyzed polyacrylonitrile containing paired metal atoms $\mathrm{Cu}, \mathrm{Co}, \mathrm{Ni}, \mathrm{Fe}$
}

\author{
I. V. Zaporotskova ${ }^{\dagger, 1}$, D. P. Radchenko' ${ }^{1}$ L. V. Kozhitov², S. V. Boroznin ${ }^{1}$, N. P. Boroznina ${ }^{1}$ \\ †irinazaporotskova@gmail.com
}

\author{
${ }^{1}$ Volgograd State University, Volgograd, 400062, Russia \\ ${ }^{2}$ National Research Technological University “MISiS”, Moscow, 119049, Russia
}

\begin{abstract}
In this work, models of a single layer of pyrolyzed polyacrylonitrile (PPAN) containing couples of $\mathrm{Cu}-\mathrm{Co}, \mathrm{Cu}-\mathrm{Ni}$, $\mathrm{Ni}-\mathrm{Co}, \mathrm{Ni}-\mathrm{Fe}$ atoms have been created. The models are PPAN clusters. A complete optimization of the models was carried out using the density functional method DFT with the B3LYP functional and the cc-pvdz basis. The atom couples under study were located in the center of the cluster. The geometric structure of the models of composite systems was investigated. A significant curvature of the simulated structures was found. The single-electron spectra of the clusters were presented graphically, and it was shown that the atomic orbitals of the metals make the main contributions to the conductivity band. The band gap is analyzed and compared with a similar characteristic of PPAN without metal atoms. It was found that the cobalt atom insignificantly affects the change in the band gap, in contrast to nickel, the introduction of which significantly reduces it. In turn, couples of $\mathrm{Cu}-\mathrm{Co}$, $\mathrm{Cu}-\mathrm{Ni}$ atoms make a greater contribution to the formation of levels of atomic orbitals in the conduction band of the system. Among the models studied, the smallest band gap corresponds to the PPAN system with a couple of Ni-Fe atoms. The energy calculation showed the presence of stable chemical bonds in the systems. The charges of metals were determined using the atomic polar charge tensor. Charge transfer from metal atoms to single layer atoms was found, which is the evidence of the formation of a chemical bond between the studied metals and the single layer.
\end{abstract}

Keywords: pyrolyzed polyacrylonitrile, DFT, quantum chemical calculations, transition metal atoms, nanocomposite.

УДК: 538.9

\section{Компьютерное моделирование композита на основе монослоя пиролизованного полиакрилонитрила, содержащего парные атомы металлов $\mathrm{Cu}, \mathrm{Co}, \mathrm{Ni}, \mathrm{Fe}$}

\author{
Запороцкова И. В. ${ }^{\dagger, 1}$, Радченко Д. П. ${ }^{1}$, Кожитов Л.В. ${ }^{2}$, Борознин С. В. ${ }^{1}$, Борознина Н. П. ${ }^{1}$ \\ ${ }^{1}$ Волгоградский государственный университет, Волгоград, 400062, Россия \\ ${ }^{2}$ Национальный исследовательский технологический университет «МИСиС», Москва, 119049, Россия
}

В данной работе были созданы модели монослоя пиролизованного полиакрилонитрила (ППАН), содержащие пары атомов металлов $\mathrm{Cu}-\mathrm{Co}, \mathrm{Cu}-\mathrm{Ni}, \mathrm{Ni}-\mathrm{Co}, \mathrm{Ni}-\mathrm{Fe}$. Данные модели представляют собой кластеры ППАН. Проведена полная оптимизация моделей с использованием метода функционала плотности DFT с функционалом B3LYP и базисом cc-pvdz. Изучаемые пары металлов размещали в центре кластера. Исследована геометрическая структура моделей композитных систем. Обнаружено значительное искривление моделируемых структур, свидетельствующее о наличии тубулярных структур в реальном композите. Графически представлены одноэлектронные спектры кластеров и показано, что атомные орбитали металлов дают основные вклады в зону проводимости. Проанализирована ширина запрещенной щели и проведено сравнение с аналогичной характеристикой ППАН, не содержащего атомов металла. Установлено, что атом кобальта незначительно влияет на изменение ширины запрещённой щели, в отличие от никеля, введение которого существенно её уменьшает. Таким образом, становится возможным создавать более электропроводящие композиты. В свою очередь в моделях, содержащих медь, атомы металлов дают больший 
вклад в образование уровней атомных орбиталей в зоне проводимости системы. Среди исследованных моделей наименьшая ширина запрещённой щели характерна для системы ППАН с никелем и железом. Расчет показал наличие устойчивых химических связей в системах. Определены заряды металлов с помощью атомного полярного тензора зарядов. Обнаружен перенос электронной плотности с атомов металлов к атомам монослоя, что является свидетельством образования химической связи между изучаемыми металлами и монослоем.

Ключевые слова: пиролизованый полиакрилонитрил, DFT, квантово-химические расчеты, атомы переходных металлов, нанокомпозит.

\section{Introduction}

Currently, due to the specific properties that appear during the transition of substances to the nanoscale state, researchers are particularly interested in composite materials consisting of a polymer matrix and a filler. One of the most popular materials in recent years is materials that can effectively absorb electromagnetic radiation. This interest is due to the increase in the number of devices operating in the microwave range, which is accompanied by an increase in the density of electromagnetic radiation. Radio-absorbing materials are used not only to ensure electromagnetic compatibility of various devices, but also to protect biological objects from negative electromagnetic impact [1-4]. Such materials include carbon-based polymer composites comprising transition metal nanoparticles such as nickel, cobalt, iron, copper [5-9]. These nanocomposites can be used in various fields of technology: magnetic recording systems, high-frequency devices, magnetic resonance tomography, biomedicine, radiation protection systems, electronics and others [10-12].

In composites, nanoscale objects are embedded in the matrix, which leads to their minimal interaction with each other and provides their protection from agglomeration and oxidation [13-17]. Metal-polymer nanocomposites are able to show synergy between the unique properties of polymers (solubility, high coordinating ability, chemical and thermal resistance, biocompatibility, etc.) and metal nanoparticles (catalytic, magnetic, optical, etc.), which makes them in demand in high-tech fields. Magnetic composites, in which ferromagnetic metal nanoparticles are embedded in nonmagnetic arrays, are of great scientific and practical interest. Unusual phenomena were found in these materials: high magnetization, a large magneto-caloric effect, the possibility of changing the values of coercive force due to the dependence of this value on the size of nanoparticles, a lower Curie temperature, high anisotropy, etc. Investigation of metal nanoparticle formation processes involving polymers enables to obtain new metal composites with controlled properties required for a specific application $[18,19]$.

The polymer matrix of nanocomposites is often polyacrylonitrile (PAN) [20]. The PAN polymer chain is a hydrocarbon chain with side nitrile groups, due to which intermolecular crosslinking and interaction with metal compounds can be carried out. Due to the presence of 5 electrons in the nitrogen atom on the outer shell, of which only 3 are involved in interaction with carbon, transition metals, due to their high coordination numbers, are able to form complexes with nitrile groups of the polymer. PAN has a number of advantages optimal for the synthesis of metal composites: manufactured on an industrial scale at Russian enterprises; due to complexation, it is able to form joint solutions with metal compounds of different concentration, which allows uniform distribution of the metal over the polymer volume.

One of the promising methods for the synthesis of nanoparticles is the pyrolysis method using IR heating of a system of transition metal salts and polyacrylonitrile (PAN). With IR heating in PAN, structuring occurs with the release of $\mathrm{H}_{2}, \mathrm{CO}, \mathrm{NH}_{3}$, etc., reducing metal salts, and the formation of a matrix of a polymer material - pyrolized polyacrylonitrile (PPAN), which has a graphite-like layer structure, in which metal nanoparticles are dispersed. The main advantages of such hybrid magnetic nanomaterials when used to absorb electromagnetic radiation are the provision of magnetic losses due to the interaction with the magnetic component of electromagnetic waves and an increase in the complex and dielectric permeability compared to individual components of the material.

To date, a number of nanocomposites have been synthesized both with single metals ( $\mathrm{Fe}, \mathrm{Co}, \mathrm{Ni}, \mathrm{Cu}, \mathrm{Pt}, \mathrm{Pd}, \mathrm{Ru}, \mathrm{Re}, \mathrm{Rh}$, $\mathrm{Ag})$ and with various binary systems of nanoparticles $(\mathrm{Cu}-\mathrm{Zn}$, Pt-Re, Pt-Ru, Co-Pd, Fe-Co, Fe-Ni, Fe-Pd, Ni-Co) [24-28]. Research is underway to develop effective methods for the synthesis of three- or more component nanoparticles. Thus, when two different metal salts were simultaneously added to the precursor, composites containing the paired FeNi and FeCo systems were obtained [27,28]. Depending on the cobalt concentration, the composites exhibited paramagnetic or ferromagnetic properties. The metal composite containing NiCo alloy nanoparticles was synthesized from precursors consisting of polyacrylonitrile, nickel chloride and cobalt chloride. The lattice parameter of the solid solution NiCo calculated from the results of PPA was $0.3527 \mathrm{~nm}$. The electrical conductivity in the nanocomposite is ensured by the formation of a graphite-like structure and depends on the size and quantity of included metal particles [28].

Despite numerous experimental studies of nanocomposites based on pyrolyzed polyacrylonitrile (PPAN), the geometric structure (morphology) and peculiarities of the electronenergy structure of these metal-carbon materials remain unexplored to date. In [22] composites based on PPAN with single atoms of transition metals were theoretically studied. It is necessary to consider the structural features of metal composites containing paired metal systems (paired alloys).

To solve the problem, it is advisable to consider a cluster model of one layer of pyrolyzed polyacrylonitrile with embedded pairs of selected atoms $\mathrm{Cu}-\mathrm{Co}, \mathrm{Cu}-\mathrm{Ni}$, $\mathrm{Ni}-\mathrm{Co}, \mathrm{Fe}-\mathrm{Ni}$, which are structural units of binary alloys in polymer nanocomposites. The choice of pairs is determined by successful experiments on the synthesis of such metal composites [24,27]. Analysis of the features of the structure 
and electron-energy structure of such a model material will allow searching for the most likely stable spatial configurations of the elements of the nanosystems under consideration, which gives detailed information on the electron-energy structure and, accordingly, the main properties (electronic, physical, magnetic, optical, mechanical), which in turn provides an opportunity to closely approach the solution of forecasting problems.

The work presents the results of calculations performed in the framework of the molecular cluster model (MK) using the DFT (Density Functional Theory) method. The hybrid functionality is B3LYP using the cc-pvdz base set. This functionality is preferred for calculations of systems with transition metals. The cc-pvdz basis, which is an analogue of the known and often used basis 6-31G (d), belongs to the group of correlatively matched basis sets and includes polarization functions $[28,29]$. The effect of cobalt and nickel in binary alloys on the peculiarities of the electron-energy structure of the composite was evaluated.

\section{Geometrical and electronic energy structure of composite sistem "PPAN+atoms of metals"}

Several models of a PPAN monolayer containing pairs of selected metals were investigated. Six carbon atoms were removed from the center of the monolayer cluster for the formation of a structure containing $70 \%$ carbon atoms, $19 \%$ nitrogen atoms, and $11 \%$ hydrogen atoms (Fig. 1). The number of atoms to be removed was determined by the possibility of creating a pore in the structure of the monolayer, the parameters of which would be sufficient to accommodate rather large of $3 d$ transition metal atoms [30] in it.

This space was filled alternately with pairs of metal atoms $\mathrm{Cu}-\mathrm{Co}, \mathrm{Ni}-\mathrm{Co}, \mathrm{Ni}-\mathrm{Cu}$ and $\mathrm{Ni}-\mathrm{Fe}$. The system geometry analysis obtained after calculations performed with full optimization revealed a significant curvature of the monolayer with the introduction of all considered pairs of atoms (Fig. 2). The distances between metal atoms are presented in Table 1.

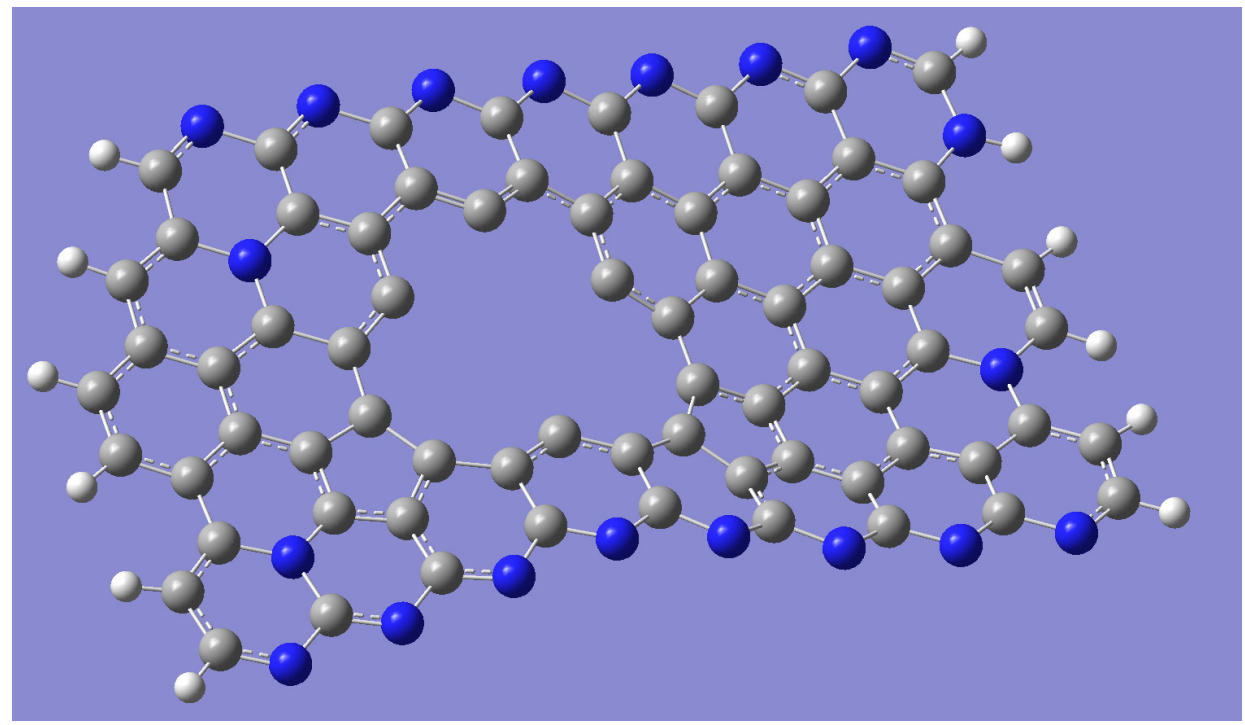

Fig. 1. (Color online) Optimized structure of PPAN clusters with a pore formed by removing six carbon atoms (grey $-\mathrm{C}$ atoms; blue $-\mathrm{B}$ atoms; white $-\mathrm{H}$ atoms).

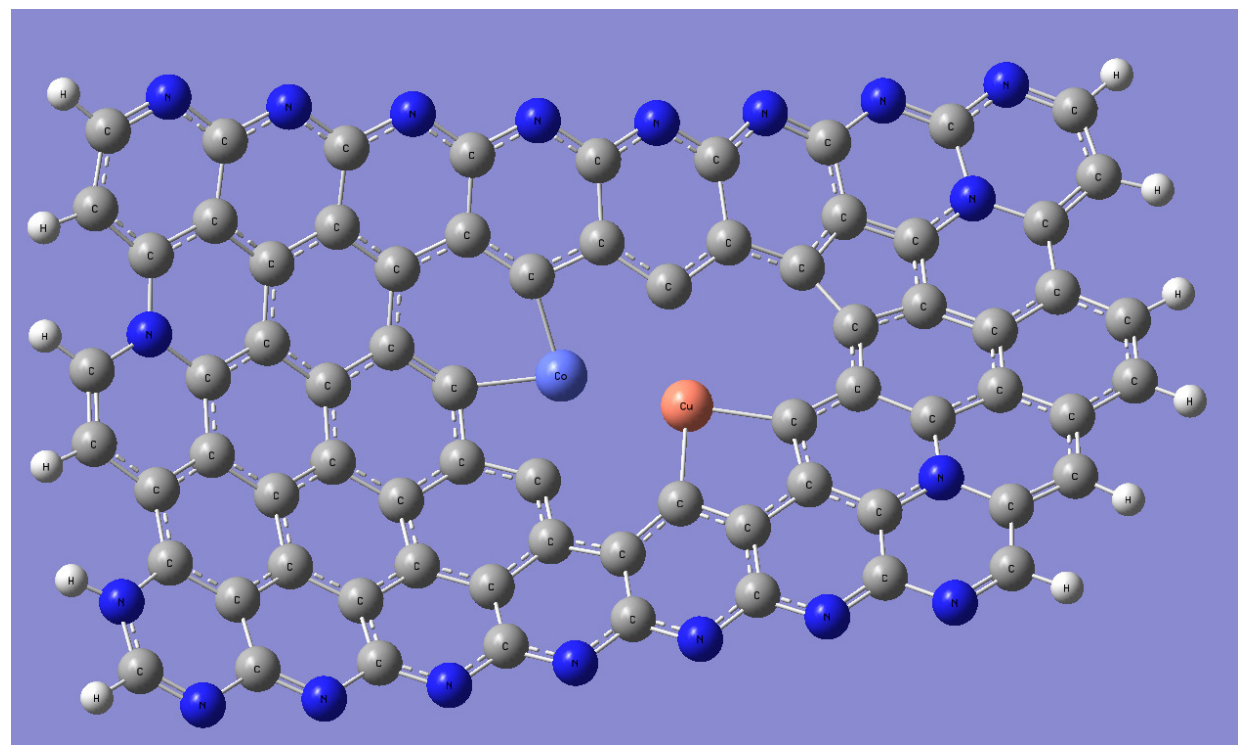

Fig. 2. (Color online) The optimized PPAN cluster with $\mathrm{Cu}$ and $\mathrm{Co}$ atoms; in the pore: left — cobalt, right — copper. 
Single-electron spectra of nanosystems were constructed, and the analysis of which allowed us to determine the band gap width, calculated as the difference between the energies of the upper filled and lower vacant molecular orbitals (Table 2). The atomic orbitals of metals make the main contributions to

Table 1. The distance between metal atoms in the monolayer PPAN.

\begin{tabular}{|c|c|}
\hline Metal atoms & Bond length, $\AA$ \\
\hline Fe-Ni & 2.57 \\
\hline Co-Ni & 3.28 \\
\hline $\mathrm{Cu}-\mathrm{Ni}$ & 2.47 \\
\hline $\mathrm{Cu}-\mathrm{Co}$ & 2.57 \\
\hline
\end{tabular}

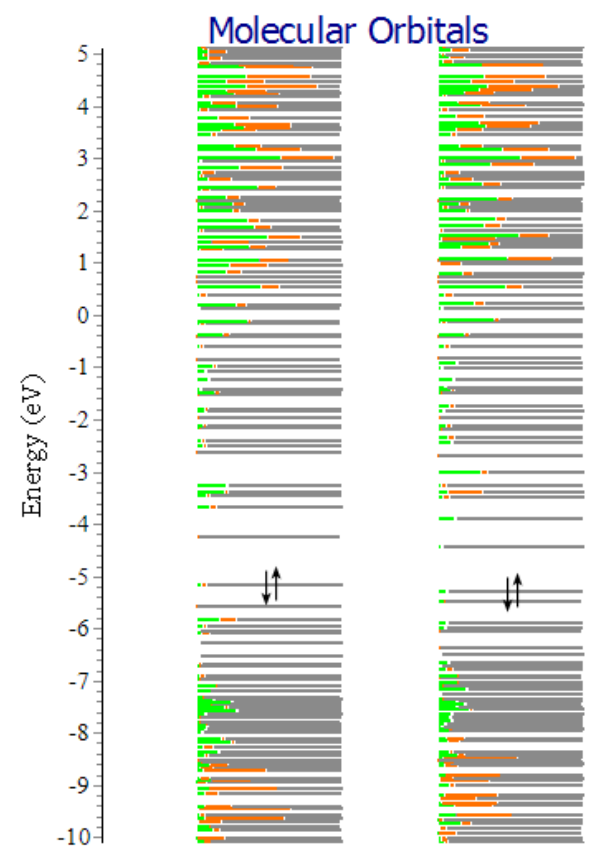

a

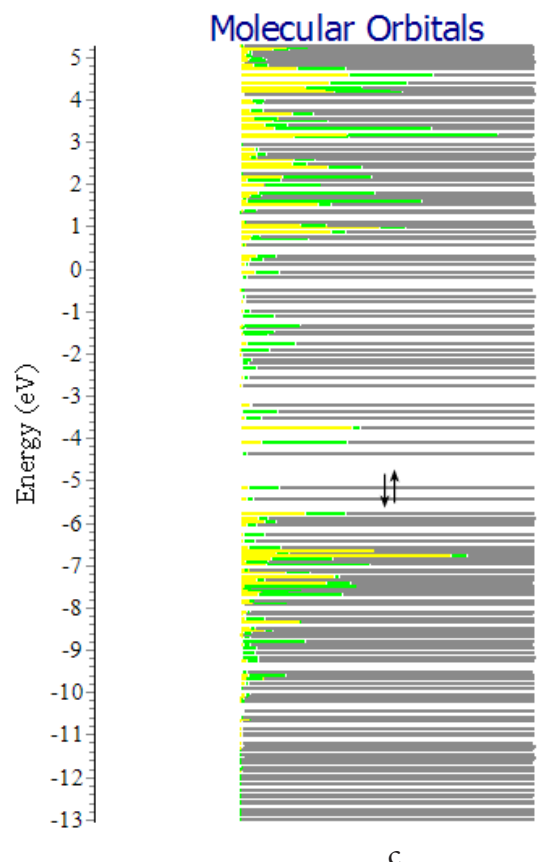

the conduction band (Fig. 3). It was established that the Co atom slightly affects the change in the band gap, in contrast to $\mathrm{Ni}$, the introduction of which significantly reduces it.

Table 2. Electron-energy characteristics of PPAN-based nanosystems with embedded pairs of metal atoms: $\Delta E_{g}$ - band gap, $E_{b e}$ - binding energy.

\begin{tabular}{|c|c|c|}
\hline Structure & $\Delta E_{g}, \mathrm{eV}$ & $E_{b e}, \mathrm{eV}$ \\
\hline PPAN & 0.98 & -9.93 \\
\hline $\mathrm{Cu}-\mathrm{Co}$ & 0.72 & -9.15 \\
\hline $\mathrm{Cu}-\mathrm{Ni}$ & 0.51 & -9.16 \\
\hline $\mathrm{Ni}-\mathrm{Co}$ & 0.95 & -9.16 \\
\hline $\mathrm{Ni}-\mathrm{Fe}$ & 0.55 & -9.19 \\
\hline
\end{tabular}

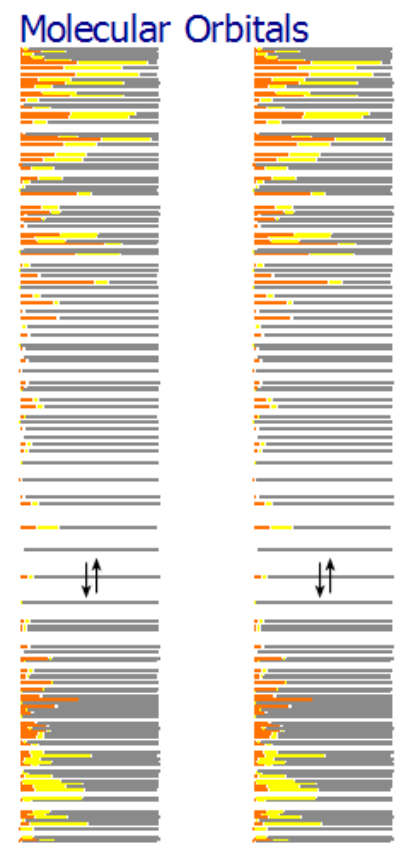

b

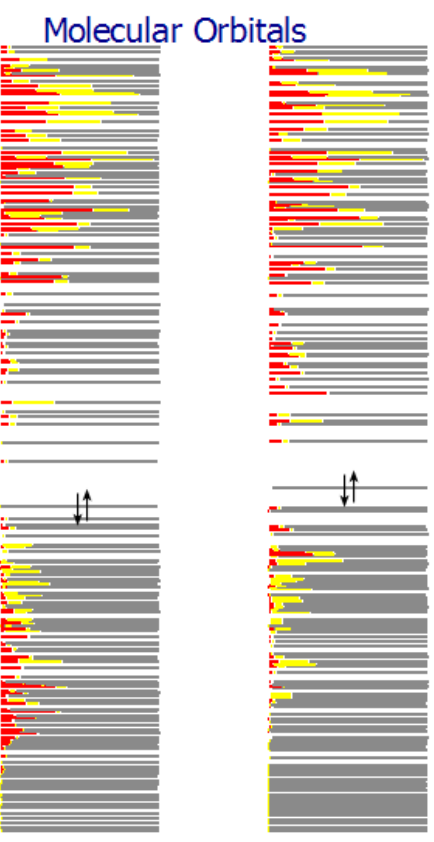

d

Fig. 3. (Color online) Single-electron spectra of nanosystems based on PPAN with embedded metal pairs: $\mathrm{Cu}-\mathrm{Co}(\mathrm{a}), \mathrm{Ni}-\mathrm{Cu}(\mathrm{b}), \mathrm{Ni}-\mathrm{Co}(\mathrm{c})$, $\mathrm{Ni}-\mathrm{Fe}(\mathrm{d})$. The orbitals of the $\mathrm{Fe}$ are highlighted in red, $\mathrm{Ni}$ - in yellow, $\mathrm{Cu}$ - in orange, $\mathrm{Co}$ - in green, others - in grey. Last occupied molecular orbital is marked by two arrows denoting electron spins. 
Also, for all studied structures, the binding energies were calculated (Table 2), the values of which turned out to be comparable with the value for pure PPAN, which confirms the stability of the obtained complexes.

The charge distribution analysis obtained by using the atomic polar tensor charge (APT charge) showed that in all cases the metal atoms are positively charged, and the atoms of the nearest environment are negatively charged. Clearly, there is a transfer of electron density from metal atoms to atoms of the PPAN monolayer. The charges of metal atoms are presented in Table 3. These results are consistent with ideas about the interaction between metals and the system of conjugated bonds in the PPAN. A shift of the electron clouds of metal to the nearest atoms of the PPAN monolayer arises.

Table 3. APT charges on metal atoms in MC.

\begin{tabular}{|c|c|c|c|c|}
\hline Metal $\backslash$ Structure & $\mathrm{Cu}-\mathrm{Co}$ & $\mathrm{Cu}-\mathrm{Ni}$ & $\mathrm{Ni}-\mathrm{Co}$ & $\mathrm{Ni}-\mathrm{Fe}$ \\
\hline $\mathrm{Fe}$ & & & & 0.724 \\
\hline $\mathrm{Ni}$ & & 0.270 & 0.565 & 0.574 \\
\hline $\mathrm{Co}$ & 0.513 & & 0.509 & \\
\hline $\mathrm{Cu}$ & 0.320 & 0.287 & & \\
\hline
\end{tabular}

\section{Conclusion}

Models of composite nanosystems based on a monolayer of pyrolyzed polyacrylonitrile with embedded pairs of $\mathrm{Ni}-\mathrm{Co}$, $\mathrm{Fe}-\mathrm{Ni}, \mathrm{Cu}-\mathrm{Co}, \mathrm{Cu}-\mathrm{Ni}$, which make it possible to determine the optimal spatial configuration of the mutual arrangement of nanoparticles and the PPAN matrix, the effect of metals on the morphology and structure of the polymer are presented. The optimal spatial configuration of a monolayer of pyrolized polyacrylonitrile containing embedded pairs of atoms was established, the features of geometric structure and electronenergy characteristics showing the characteristics of the interaction of nanoparticles and a matrix of nanocomposites were studied.

Theoretical studies have proved that the investigated metal-carbon nanosystems based on a monolayer of pyrolyzed polyacrylonitrile with embedded pairs of $\mathrm{Ni}-\mathrm{Co}, \mathrm{Fe}-\mathrm{Ni}$ and $\mathrm{Cu}-\mathrm{Co}, \mathrm{Cu}-\mathrm{Ni}$, are stable systems. The distances found between metal atoms made it possible to conclude that they correspond to the interatomic distances in the cubic lattice, which proves the fact that there are not isolated atoms in the layered polymer, but a binary alloy consisting of selected and considered iron, cobalt and nickel atoms of the compositions $\mathrm{NiCo}, \mathrm{FeNi}, \mathrm{CuCo}$ or $\mathrm{CuNi}$. The introduction of metals into PPAN leads to a decrease in the width of the energy gap compared to pure pyrolyzed polyacrylonitrile due to the appearance of additional metal levels near the slot boundary. By type of conductivity, the system refers to semiconductors. Such metal composites can be used as new magnetically soft materials having the ability to absorb electromagnetic radiation due to possible electron transitions using the emerging levels of metal atoms. The obtained results will allow us to further begin to study the features of the formation of metal clusters in the structure of the PPAN.

Acknowledgments. The reported research was funded by grants of the President of the Russian Federation No. 798.2019.1 and No. MK-1758.2020.8.

\section{References}

1. L. Y. Zhu, X.J. Zeng, M. Chen, R.H. Yu. RSC Adv. 7, 26801 (2017). $\underline{\text { Crossref }}$

2. Y.J. Li, R. Wang, F.M. Qi, C. M. Wang. Appl. Surf. Sci. 254, 4708 (2008). $\underline{\text { Crossref }}$

3. J. W. Liu, R. C. Che, H. J. Chen, F. Zhang, F. Xia, Q. S. Wu, M. Wang. Small. 8, 1214 (2012). Crossref

4. M.S. Cao, X.L. Shi, X.Y. Fang, H.B. Jin, Z.L. Hou, W. Zhou. Appl. Phys. Lett. 91, 203110 (2007). Crossref

5. X.G. Liu. Journal of Physics D: Applied Physics. 42, 1 (2009). Crossref

6. C. Zhang, B.C. Wang, J.Y. Xiang, C. Su, C.P. Mu, F. S. Wen, Z. Y. Liu. ACS Appl. Mater. Interfaces. 9, 28868 (2017). Crossref

7. M.V. Shuba, A.V. Melnikov, A.G. Paddubskaya, P. P. Kuzhir, S. A. Maksimenko. Phys. Rev. B. 88, 045436 (2013). Crossref

8. O. Khani, M.Z. Shoushtari, M. Jazirehpour, M. H. Shams. Ceramics International. 42 (13), 14548 (2016). Crossref

9. C. Li, J. Sui, Z. Zhang, X. Jiang, Z. Zhang, L. Yu. Chemical Engineering Journal. 375, 122017 (2019). Crossref

10. L. V. Kozhitov, V. V. Kozlov, A. V. Kostikova, A. V. Popkova. Russian Microelectronics. 42, 498 (2013). Crossref

11. A.I. Gusev. Nanomaterials, nanostructures and nanotechnologies. Moscow, Phizmatlit (2009) 414 p. (in Russian) [А.И. Гусев. Наноматериалы, наноструктуры, нанотехнологии. Москва, Физматлит (2009) 414 с.]

12. E. Roduner. Nanoscopic Materials: Size-Dependent Phenomena. Cambridge, UK, RSCPublishing (2014) 286 p.

13. J. Xu, X. Han, H. Liu, Y.Hu. Colloids Surf. A. 273, 179 (2006). $\underline{\text { Crossref }}$

14. R. Zana. Adv. Colloid Interface Sci. 97, 205 (2002). Crossref

15. A.D. Pomogailo, A.S. Rosenberg, I.E. Ufliand. Nanoparticles of metals in polymers. Moscow, Chemistry (2000) 672 p. (in Russian) [А. Д. Помогайло, А. С. Розенберг, И. Е. Уфлянд. Наночастицы металлов в полимерах. Москва, Химия (2000) 672 с.]

16. A. D. Pomogailo. Ros. Chem. J. 5, 64 (2002). (in Russian) [А. Д. Помогайло. Рос. хим. ж. 5, 64 (2002).]

17. V.A. Bogatirev, L. A. Dykman, N. G. Hlebtsov. Methods of synthesis of nanoparticles with plasma resonance. Manual. Saratov, Saratov State University (2009) 35 p. (in Russian) [В. А. Богатырев, Л. А. Дыкман, Н. Г. Хлебцов. Методы синтеза наночастиц с плазменным резонансом. Пособие. Саратов, изд-во Саратовского гос. ун-та (2009) 35 с.]

18. C. Rao, A. Müller, A.K. Cheetham. The chemistry of nanomaterials. Weinheim, Wiley-VCH Verlag $\mathrm{GmbH} \&$ Co. K Ga A. (2004) 741 p. Crossref

19. T. Sato. Stabilization of Colloidal Dispersions by Polymeric Adsorption. New York, Marcell Dekker (1980) $357 \mathrm{p}$.

20. H. Khayyam, R.N. Jazar, S. Nunna, G. Golkarnarenji, K. Badii, S. M. Fakhrhoseini, S. Kumar, M. Naebe. Progress in Materials Science. 107, 100575 (2020). Crossref

21. D.G. Muratov, E.V. Yakushko, L.V. Koshitov, A. V. Popkova, M.A. Pushkarev. Izvestiya Vysshikh Uchebnykh Zavedenii. Materialy Elektronnoi Tekhniki. 
1, 61 (2013). (in Russian) [Д. Г. Муратов, Е. В. Якушко, Л.В. Кожитов, А.В. Попкова, М.А. Пушкарев. Известия высших учебных заведений. Материалы электронной техники. 1, 61 (2013).] Crossref

22. I. V. Zaporotskova, L. V. Kozhitov, N.A. Anikeev, O.A. Davletova, D.G. Muratov, A.V. Popkova, E. V. Yakushko. Izvestiya Vysshikh Uchebnykh Zavedenii. Materialy Elektronnoi Tekhniki. 66, 134 (2014). (in Russian) [И.В. Запороцкова, Л.В. Кожитов, Н.А. Аникеев, О.А. Давлетова, Д.Г. Муратов, А.В. Попкова, Е.В. Якушко. Известия высших учебных заведений. Материалы электронной техники. 66, 134 (2014).] Crossref

23. K.A. Bagdasarova, L. M. Zemtsov, G.P. Karpacheva, N.S. Perov, A.V. Maksimochkina, E.L. Dzidziguri, E. N. Sidorova. Solid State Physic. 50, 718 (2008). (in Russian) [К.А. Багдасарова, Л.М. Земцов, Г.П. Карпачева, Н.С. Перов, А.В. Максимочкина, Э.Л. Дзидзигури, Е.Н. Сидорова. Физика твердого тела. 50, 718 (2008).] Crossref

24. D. G. Muratov, L. V. Kozhitov, I. V. Zaporotskova, V.S. Sonkin, N.P. Boroznina A.V. Popkova, S. V. Boroznin A. V. Shadrinov. Synthesis and properties of nanoparticles, alloys and composite nanomaterials based on transition metals. Volgograd, Izd. VolSU (2017)
650 p. (in Russian) [Д. Г. Муратов, Л.В. Кожитов, И. В. Запороцкова, В.С. Сонькин, Н.П. Борознина, А. В. Подкова, С. В. Борознин, А. В. Шадринов. Синтез и свойства наночастиц, сплавов и композиционных наноматериалов на основе переходных металлов. Волгоград, Изд-во ВолГУ (2017) 650 с.]

25. S. P. Gubin, Yu. A. Koksharov, G. B. Khomutov, G. Yu. Yurkov. Russ. Chem. Rev. 74 (6), 489 (2005). Crossref

26. V. V.Kozlov, G. P. Karpacheva, V. S. Petrov, E. V.Lazovskaya. High molecular weight compounds. Serie A. 43, 23 (2001). (in Russian) [В.В. Козлов, Г.П. Карпачева, B. С. Петров, Е.В. Лазовская. Высокомолекулярные соединения. Серия А. 43, 23 (2001).]

27. T. F. Marinca, I. Chicinaş, O. Isnard, V. Pop, F. Popa. Journal of Alloys and Compounds. 509, 7931 (2011). Crossref

28. R. van Eldik, J. Harvey. Theoretical and computational inorganic chemistry. London, Academic Press (2010) $536 \mathrm{p}$.

29. W. Koch, M. Holthausen. A Chemist's Guide to Density Functional Theory. Weinheim, Wiley-VCH, Germany (2002) 306 p. Crossref

30. O.A. Kakorina, I. V. Zaporotskova, L.V. Kozhitov, A.V. Popkova. Journal of Physics: Conference Series. 1281, 012031 (2019). Crossref 